\title{
Model of Innovative System of Enterprise Management
}

\section{Olga Tkacheva}

\author{
Candidate of Technical Sciences, Associate Professor, Head of Economics and Law Department, \\ Deputy Director of Educational Activities, Shakhty Branch of M.I. Platov South-Russian State Polytechnic University (NPI), \\ i.tkachev@inbox.ru

\section{Natalia Arkhipova} \\ Candidate of Sociological Sciences, Associate Professor, Department of Economics and Law \\ Shakhty Branch of M.I. Platov South-Russian State Polytechnic University (NPI), arxipnju@mail.ru
}

\section{Anatoliy Chistyakov}

Doctor of Sociological Sciences, Professor, Department of Economics and Law, Shakhty Branch of M.I. Platov South-Russian State Polytechnic University (NPI), afrika28@yandex.ru

\section{Elena Fandeeva}

Candidate of Philosophical Sciences, Associate Professor, Department of Economics and Law, Shakhty Branch of M.I. Platov South-Russian State Polytechnic University (NPI), fandeevaem@yandex.ru

Aleksey Ivanov
Candidate of Juridical Sciences, Associate Professor, Department of Economics and Law,
Shakhty Branch of M.I. Platov South-Russian State Polytechnic University (NPI)

Doi:10.5901/mjss.2015.v6n3s6p147

\section{Abstract}

The purpose of the article is to develop a model of innovative system of enterprise management. This purpose is achieved with the help of the following methods: induction, deduction, synthesis, comparative and problem analysis, and systemic approach. The authors study the existing models of managing innovative activities of enterprises, analyze the conditions of functioning of modern enterprises, and offer the proprietary model of management of innovative system of enterprise. As a result of the research, the authors concluded that at present there is no model of management of innovative activities under conditions of the crisis. Therefore, it is advisable to form a new model of management of innovative activities of enterprise under conditions of the crisis, built on a comprehensive and systemic evaluation of its results, specifics of formation and use of innovative potential, innovative activities of enterprises, and overcoming existing and prevention of potential innovative risks of the economy. For the purpose of overcoming this drawback, the authors developed the model of innovative system of enterprise management which takes into account a risk component of innovative activities and consists of external environment, including entry and exit, connections with outer environment, and feedback, and internal structure - a variety of interconnected components that ensure the process of the subject's influencing the object, transition of entry into exit, and achievement of goals.

Keywords: innovative system, enterprise management, innovative economy.

\section{Introduction}

In light of continuing problems in the global economy and necessity for provision of stability of economy, there arose an idea of transition to the economy which is based on the use of innovative technologies and manufacture of innovative production. That's why a lot of enterprises try to implement new technologies into their production and manufacture new products that have no analogues in the market. Most of these examples are from one time projects, while this kind of work supposes constant and systematic perfection and development of product line and technologies. 
Transition to innovative economy supposes organization of innovative activities at the industrial enterprises as a part of their main operations. In order to gain the advantage over the rivals, an enterprise has to constantly control innovative activities, track new tendencies in the market, support two-way interaction with clients, and constantly implement new products and technologies.

Besides, innovative activities require the participation of a lot of employees, who are specialists in various spheres, which may create a problem of goals determination, resource and responsibilities distribution, be a reason for overspending during development and implementation of innovation, and force the company to abandon that activity. All of this shows that in order to effectively use the innovations, it is necessary to create a system of management which will allow managing the innovative activities of an enterprise in an effective way.

\section{Research Methods}

Many of the modern industry-oriented economic systems are characterized by the striving for transition to a whole new level of development through the change of industrial direction to innovative one. However, this is largely hindered by a high level of uncertainty of external environment, which brings up additional risks. Under these conditions, stable development of macro-economic system requires parameters that form the factors of success of innovative activities results. Primarily, these include flexibility of methods for management of entrepreneurial activity subjects, adaptability to change of factors of environment, creativity of enterprise's personnel, striving for innovative activities with development of various objects of intellectual property and bringing the received results of intellectual activity to practical use.

Forming the innovative economy requires creation of corresponding infrastructure. This infrastructure should be a place for effective realization of new forms of management of processes of creation and commercialization of innovations (results of intellectual activity), new forms of interaction of the members of innovative activities, and new forms of financing of these activities. Implementation of innovative programs and separate innovative projects in the economy requires attraction of large volumes of capital that is necessary for financing various expenses (investment and current). These expenses emerge in various spheres of innovative activities. It may be a sphere of basic scientific research and applied R\&D; sphere of technological re-equipment of industrial base of an enterprise; sphere of acquisition of manufacture of new (pioneer innovations) and modernized (improved innovations) production, etc.

Orientation of subjects of global macro-economic system at innovational paradigm of development led to emergence of new trends in economy. Firstly, it is the complexity of effect, reached in the sphere of creation and use (commercialization) of innovational developments. Secondly, forming global scientific centers and quickening of international integration in scientific and industrial sphere. Thirdly, intensification of processes of scientific research and of commercialization of received results of intellectual activities.

This leads to expansion of innovative macro-economic system, for example, by means of forming new sources of innovational ideas. In the global economy, innovational sources appear not only from ideas that are formed within innovational programs and projects, which are performed directly by scientific and educational establishments and industrial enterprises, but also from ideas that are formed by the market. This leads to a "subsystem of open innovations" appearing in macro-economic innovative system. Besides, innovative nature of development of macro-economic system dictates the emergence of new demands in society, formation of a new way of life, strengthening of spiritual component of society development, and growth of sensitivity to practical realization of innovative ideas in various spheres of human activity.

Innovative activities are most characteristic of enterprises which comprise high-tech spheres of industry. The subjects of these spheres possess a significant intellectual potential, and some have a high export potential. The subjects of high-tech spheres of industry are, as a rule, large structures which include scientific departments and universities, oriented at solving scientific, technical, and economic tasks that emerge under conditions of competitive market.

However, in order to realize the created potential, a state support for high-tech spheres of industry is needed. Primarily, state support should be granted for the structures which generate innovative projects that provide cumulative effect at the level of a sphere, region, or economy as a whole. Implementation of these projects allows strengthening technological leadership of the country in a variety of spheres by means of creating technologies (process innovations) and products (product innovations). That's why there emerges a task of improving the efficiency of export of high-tech products, for example, through state guarantees for exporters.

Effective development of industry is facilitated by state support for "import" of technological competencies. This requires creation of macro-economic conditions for formation of new high-tech companies, including joint enterprises with leading global producers. In this regard, the role of actual financial strategies belongs to strategies which are based on seed and venture financing, which supposes perfecting the activities of development institutes, stimulation of the 
processes of enterprises capitalization, and improvement of the models of organization of product innovations manufacture, including by means of involving foreign investors into creation of new high-tech enterprises and manufactures (Smakhtina, 2013).

Such a strategy of industry development can provide success in the rivalry with foreign manufacturers in the global markets of science-based high-tech products. This situation requires formation of main conditions for effective provision of innovative activities by high-tech enterprises of various spheres of industry. The most important of these should be increasing the efficiency of state support, including provision of state guarantees at the entry of high-tech enterprises of industry to global markets of high-tech and science-based production, and perfecting legal basis of innovative activities.

Innovative activities management is a process of control of a complex dynamic system. It is impossible to provide the efficiency of such system's functioning without its modeling. At present, foreign and domestic practice uses a lot of models of innovative activities management. However, despite a large variety of existing models of innovative development, all these models - depending on orientation of innovative activities - may be united into two groups. These models are based on various approaches to the processes of managing the innovative sphere and methods of commercialization of received results of intellectual activities (created innovations). These groups of models include (Batashova, 2013):

The first group includes linear models of innovative activities management. These are traditional managerial models, in which the process of creating new technologies (process innovations), products (product innovations), and development of methods of industrial system building and managing them (organizational and managerial innovations) is viewed as an algorithm, based on a strict sequence of steps. This sequence begins with the fundamental scientific research, at which stage an innovative idea emerges. Then there goes a stage of applied research and R\&D work, including creation of test prototype, and then - marketing, constructive, technological, and organizational preparation of production, and organization of final innovation issue. The sequence ends with commercialization of the received results of intellectual activities. The basis of linear models is technical, financial, and intellectual possibilities of an enterprise in the sphere of scientific research and R\&D work. Fundamental research is performed, as a rule, by organizations of Russian Academy of Sciences. Though the sphere of marketing and commercialization of innovations are related to the market in these models, however, linear models of innovative activities management are not market-oriented.

The second group includes non-linear models of management of innovative activities. This group includes interactive models in which the process of innovative development is viewed as a complex dynamic system of management. In the process of functioning, this system is influenced by managing and disturbing (market) signals. Reaction to these processes is represented by correction of the process of functioning of the system of innovative activities management. This system includes reverse connections, reflecting interconnections between results of intellectual activities and managing influences of the subjects of various levels of innovative activities management.

Using these models will provide a cardinal increase of efficiency of innovative activities. To a large extent, this will be achieved by means of modeling the processes of realization of complex, science-based innovative processes, including the projects that are implemented under conditions of public-private partnership. In its turn, modeling supposes the detailed development of planned innovative projects and programs. This development should include participation of all parties of partnership, society, and various categories of market stakeholders. At the macro-economic level, the development of innovative projects and programs should be performed by chambers of commerce and industry, sectorial and regional employers' associations, and various regional institutes, including charity institutes.

\section{Results}

During creation of the model of innovative system of enterprise management, there may arise a question, which system of management will allow managing innovative activities in the most effective way? To answer this question, it is necessary to understand what innovative activity is. R. Rothvell suggests viewing innovative activities as a process (Rothvell, 1993). Based on his classification of innovative processes, innovative activities are viewed as a process of implementing changes which consists in transformation of scientific and technical ideas into the result that has practical use. This "transformation" includes such stages as applied research (fundamental, exploratory, applied), designing and R\&D work, and implementation of innovations (production, sale, improvement).

As innovative activities are viewed as a process, it is necessary to determine what this process means for the work of an enterprise. Based on definitions of such authors as T. Davenport, M.E. Porter, and V.E. Millar, there was created a unified definition, according to which a process, or business process, is a total of various types of activities (operations, functions), which transform entries into exits (resource) and together create a result (product, service) that has value for consumer, client, or customer (external or internal) (Porter and Millar, 1985; Davenport, 1993). 
On the basis of aggregate definition of business process, it becomes obvious that it is a variety of operations that transform the received information and resources into a product that has a value for a consumer. In its turn, innovative activity is a variety of operations (research, design work, manufacture of product and its realization) that transform the received information on demands of the market and resources in the form of technologies into innovational product that has a value for consumer. This comparison of two notions shows that innovative activities of an enterprise may be controlled, as if it were a business process, using the principles of process management. However, it does not show what principle of process management should be used and how an innovational process should function.

In order to understand that, there was conducted an analysis of the types of process management and their main differences. It was found that modern management includes two main types of process management: "functional" and the one based on "through" business processes. Allocation of the processes in the functional type is achieved by connecting the system of business processes to the "functional" departments of an enterprise. Thus, within the activities of each department (marketing, sales, financial department, etc.), a process is allocated that determined the direction of its activities (process of marketing, sales, finances management). Management, based on "through" processes, supposes that a process is a description of a sequence of works, performed by various departments of enterprise, united by the final result.

For determining the type of innovational process, there is a matrix for choosing the type of process management of innovative activities of an enterprise (Table 1). This matrix included four possible variants of managing innovative activities as a business process: as a separate "through" business process, as a separate "functional" business process, as a part of enlarged "through" business process, and as a part of existing "functional" business process.

The choice of a certain type of process management according to the matrix depends on two criteria: level of development of innovative activities of enterprise and interest of management in the development of innovative activities. Within the matrix, each of the criteria receives a factual value: high or low. If the level of development of innovative activities is high, it should be managed as a separate business process. The type of management to be chosen at the high level of development of innovative activities depends ono the level of interest of enterprise's management in its development. If the level of management's interest is low, it is possible to say that it will most likely not agree to change the existing organizational structure - that means there could be only "functional" type of management. If the management's interest in the development of innovative activities if an enterprise is high, it will most likely agree to change the organizational structure substantially, and the creation of innovational process will require a "through" type of process management. If the level of development of innovative activities at the enterprise is low, the most suitable variant is managing innovational process as a part of a larger business process with a possibility for its further detachment into separate business process (Iskoskov and Sosunova, 2015).

As was described above, a "through" process management requires a serious change of its organizational structure. It is not clear how the management of innovational process should be realized without serious changes into enterprise's organization. According to the author, the best decision is to use the combination of "functional" and "through" types of process management. Peculiarities of this approach consist in the fact that "functional" and "through" business processes at the enterprise are used simultaneously, and the processes of creation of value for a customer are formed as "through" processes, while the rest of enterprise's processes are formed according to the functional structure.

Algorithm of allocation of business processes according to the offered approach included two stages. At the first stage, based on the collected data in the structure and operations within the enterprise, and according to set goals of implementation of process management, there is a unification of activities of "functional" departments.

At the second stage, the received "functional" structure is divided into one, creating a value for a client and the one providing the activity that creates a value. The processes that participate in creation of a value for customer are united into a single process as to general criterion (product/service, consumer, technology), independent of belonging to a certain department.

The activities that ensure the provision of creating a value for customer are united into functional processes according to the object of activity (personnel, informational technologies, finances). The reorganization leads to formation of a new process structure, based on a "combined" approach, uniting "functional" and "through" processes.

The question, which business process is innovational process related to, remains open. In order to answer it, the authors analyzed which stages are included into innovational process. According to the data received, innovational process of industrial enterprise may be divided into five main stages: fundamental and applied research, idea development, marketing approbation of idea, manufacturing application, and sale.

It is obvious that innovational process included a part of main operation of an enterprise - in other words, it partly replicated the process of creating value for customer. On this basis, it is possible to conclude that the most optimal method of integration of innovational process into the system of process management is its unification with business 
process of creating a value for customer. This model possesses a variety of advantages. The "through" approach to the enterprise's processes allows avoiding the division of innovational process into tasks that belong to various main processes of enterprise, which wouldn't allow managing the innovative activities of enterprise effectively. Also, it allows avoiding double subordination of employees that perform operations which belong to different business processes of an enterprise.

Specifics of innovative activities consists in its uncertainty and postponed result, mismatch of public and individual effects, asymmetry of information accessible for researchers, innovators, and potential consumers; high investment risks; special requirements for personnel qualification and managers' quality.

Innovative activities management is changes in purposes of implementation and use of new types of equipment, processes, and renewal of various sides of innovative activities of an enterprise. Experience of leading enterprises shows that innovations are inevitable and uncontrolled. Innovative activities management is a key to sustaining a high efficiency of production.

At that, the management process takes place under conditions of the crisis. It should be noted that implementing innovative activities under conditions of the crisis is a recipe for success. Thus, the meaning of innovative activities under conditions of the crisis is expresses in the following:

1. allows adapting to changing conditions with the least losses;

2. is one of the main conditions for survival in unstable situation, competitive struggle, and a source of development;

3. despite the decrease of wages and income, which leads to decrease of demand for products from customers, it facilitates the full satisfaction of consumers' demand with the growth of products' quality;

4. facilitates the support for production's efficiency;

5. preserves financial results, ensuring their further increase;

6. increases enterprise's image and its competitive status;

7. strengthens partnership connections;

8. improves organizational structure;

9. improves staff's qualification which ensures the growth of labor efficiency.

Considering this, managing innovative activities of enterprise during the crisis is a systemic process of organizational influence on innovative activities from the management of enterprise through implementation of measures aimed at restoring, preserving, and strengthening competitiveness of enterprise, providing stability during the crisis and further economic growth of enterprise.

The conducted analysis of existing models of innovative activities development showed that as of now there is no model of innovative activities management under conditions of the crisis. That's why it is advisable to form a new model of managing innovative activities of enterprise during the crisis, built on a comprehensive and systemic evaluation of its results, specifics of formation and use of innovative potential, innovative activity of enterprises, and on the overcoming existing and preventing the potential innovational risks under unstable conditions of economy.

Model of management of innovative activities during the crisis consists of external environment, which includes entry and exit, connection with outer environment, and feedback, and internal structure - variety of interconnected components that ensure the process of management subject's influence on the object, transition of entry into exit, and achievement of goals.

As to the context essence of economic nature and possibility\&conveniency of formalization of such complex and multi-sided category as innovative activity, the process of modeling its content, attributes, and connections is reflected in a form of cybernetic chain according to the principle of "black box" which has entry - purposes and tasks of innovative activities, and exit - results of innovative activities; at that, the results cooperate with purposes and tasks with the help of feedback, correcting them, as if it were a processor of "black box" - a transformer of set goals into results of innovative activities of enterprise - innovative activities which possess a high level of uncertainty and probabilistic nature under conditions of the crisis, which is strongly influenced by external environment. External environment is a total of external subjects and forces (factors) which influence the development of innovative activities (Jongen et al., 2015).

In the model of management, the managed subsystem - innovative system of enterprise, managing subsystem enterprise's managers, the managing functions of which include strategic marketing, planning, organization of processes, account and control, motivation, regulation, and coordination.

Organizing innovative activities includes creation of corresponding material and technical conditions, financial, personnel, informational, and other types of provision of innovative activities.

The regulatory function consists in development and implementation of measures, aimed at changing the state of innovational process and conditions of its flow. Regulation is conducted through integration of innovative relations: 
combining interests and actions of their members and overcoming difficulties at the "joints" between them (Okrepilov and Leonidov, 2015).

Motivation for managing innovative activities of enterprises is a complex of administrative, economic, and sociopsychological influences which stimulate innovations. The sense of this managerial influence is development of scientifically substantiated system of material stimulation of enterprises which consists in additional subsidizing, benefits, increased wages, etc.

Coordinated functions of innovative activities include establishment of communications, organization of interaction, and coordination of work of innovative system components.

For the purpose of successful realization of development and innovational strategies, creation of innovational climate, and dynamic tracking of innovational positions of organizations at enterprise, an innovative system of enterprise is formed. Innovative system is a part of production and economy system of enterprise, the elements of which participate in innovational process and innovational transformations to the fullest extent. Total elements of innovative system can ensure innovational transformations (Popkova and Tinyakova, 2013a).

Innovative system includes complex interconnections between its elements in the process of dynamic development and external environment's influence, so its study should be performed with the help of systemic analysis. Systemic analysis is a methodological means of systemic approach to solving problems in the innovational sphere. Thus, let us determine its principles, set on the basis of management model of enterprise's innovative activities:

- integrity and complexity - viewing the innovative activities of enterprise as a single whole, determining all existing interconnections within innovative system and between the system and external environment;

- invariability - various alternatives (means and methods) for achieving innovational goals;

- $\quad$ optimality - considering possible variants of the state and structure of innovative system, its organization and innovational processes, which take place within it, for the purpose of choosing preferable solutions;

- dynamic character - considering the development of innovative activities, dynamic interconnections in time, not in statics;

- structuring - possibility for studying structure, internal form, or organization of innovative system in view of integrity of interconnections between its elements;

- functionality - joint consideration of structure and functions with functions being of higher priority than structure.

Top-management of a company is an initiator of implementation of rather new products than new technologies. The role of external investors, external consultants, members of linear departments and external R\&D organizations is very small. Experience of innovators B. Gates, A. Morito, D. Welch, K. Matsushita, and S. Jobs, who led their companies to global leadership, is well-known. Successful innovators-managers combine three capabilities very smoothly: in technique, planning, and sale. Attention should be paid to the example of M. Dell, who, having founded Dell Computers in 1984 at the age of 19, became the youngest American CEO of the company that was included in Fortune 500. In 2004, Dell was the sixth in global list of companies that were the mostly admired. In 2005, according to Forbes, M. Dell, having USD 18 billion, was the fourth richest person in the USA (Cui and Wu, 2015).

The secret of Dell's success consists in an idea which was revolutionary at that time - selling computers not through intermediaries, but directly. As a result, he was able to achieve advantage as to price (saving on intermediary's commission). Having direct contact with buyer, Dell - thanks to instant feedback - received information about unsatisfied demands and results of test marketing of its new products. Partnership with buyer and direct contact gave Dell the possibility to react to market changes and create increased consumer value faster than their opponents. When M. Dell created a new business model, many would say that it wouldn't work.

The above examples show that innovative activity is receiving socio-economic effect by means of effective use of intellectual capital of an enterprise. Intellectual capital is a body of knowledge and pseudo-material values, acquired during cognitive process of human, which are used in activities of economy subjects and which give competitive advantages. It is a certain aura, surrounding material capital and bringing it into motion for achieving the organization's purposes. According to the World Bank data, at present, only $16 \%$ of economic growth is caused by development of physical capital, $20 \%$ - by natural capital, and other $64 \%$ - by human capital. In the epoch of informational economy, up to $40 \%$ of gross national product is acquired by developed countries as a result of using the effective system of education (Zhang et al., 2015). The global market of intellectual products and services is 5 times faster than traditional markets. Intellectualization of technologies in use ensures the quick increase of labor efficiency. A vivid example of this is Japan a country with high-tech industry. During 43 years (1968-2009) Japan was holding a second position in the world, with only the US ahead. Only in 2010 China overcame Japan (Popkova and Tinyakova, 2013b). 
Activation of innovative activities of enterprise will be positively influenced by implementation of a system of management of level of intellectual capital which includes intellectual potential, formed of human, infrastructure, and marketing assets and intellectual property, and the result of its implementations, expressed in added value for the estimated period.

Intellectual capital is often "idle" at many enterprises. Management of intellectual capital is rarely pointed out as a priority of strategic development of business; it is rarely estimated, and no one is responsible for managing such a powerful instrument of providing an enterprise's competitiveness. Balance sheet reflects only small part of intellectual capital in the form of non-material assets. Accounting and managing such an important and valuable capital will ensure the formation of competitive advantages and increase of efficiency of enterprise's capital.

\section{Conclusion}

On the basis of the above mentioned, it is possible to conclude the following: firstly, low innovational activity of modern enterprises is primarily caused by the fact that the practice of their management lacks a systemic approach to managing risks of innovative activities. Absolute majority of successful companies have a peculiar feature - the culture of management of these companies has a "wheel of innovations with a risk component", an organizational and managerial mechanism of accompaniment of the whole life cycle of innovations from formation of ideas to implementation of result in the market.

Secondly, innovations are implemented in phases, so in order to successfully realize an innovational decision, an enterprise should have organizational and managerial mechanisms ("spokes of innovations wheel"), which support innovational processes at all stages of its life cycle. Thirdly, a company should have a high-ranking manager of creative nature (leader-innovator), who, firstly, starts the "wheel of innovations under risk component" and, secondly, sets the direction of its movement.

Naturally, his initiatives should have the support of the staff and managers who are in charge of innovative activities of the company. Fourthly, innovative activity is, as a matter of fact, acquisition of socio-economic effect by means of effective use of intellectual capital of enterprise, so enterprise requires implementation of system for management of intellectual capital.

It may be concluded that peculiarities and methods of forming the system of management of innovative activities by means of process management, which are viewed in the article, are the basis for providing any industrial enterprise with a possibility for quick reorganization of its own system of management and transition to effective innovative activities.

\section{References}

Batashova, A.F. (2013). Using the indicator for innovational potential in management of coal-mining enterprises // Economic and entrepreneurship. - 2013. - No.3. - Pp. 265-269.

Cui, A.S., Wu, F. (2015). Utilizing customer knowledge in innovation: antecedents and impact of customer involvement on new product performance. Journal of the Academy of Marketing Science, 3, 12-17.

Davenport, T. H., (1993). Process innovation: reengineering work through information technology. Boston: Harvard Business School Press.

Iskoskov, M.P., Sosunova, L.A. (2015). Methodology for formation of the cost of the innovation project. Asian social science journal, 11(8), 162-172

Jongen, W., Burazeri, G.,Brand, H. (2015). The influence of the economic crisis on quality of care for older people: system readiness for innovation in Europe. Innovation journal, 3, 25-29.

Okrepilov, V.V., Leonidov, M.V. (2015). Economics of quality - the basis of innovative development and ensuring the quality of life. Asian social science journal, 11(7), 312-325.

Popkova E.G., Tinyakova V.I. (2013). New Quality of Economic Growth at the Present Stage of Development of the World Economy. World Applied Sciences Journal. 2013a, 24(5): Pp. 617-622.

Popkova E.G., Tinyakova V.I. (2013). Drivers and Contradictions of Formation of New Quality of Economic Growth. Middle-East Journal of Scientific Research. 2013b, 15(11): Pp. 1635-1640.

Porter M. E., Millar V. E., (1985). How Information Gives You Competitive Advantage. Harvard: Harvard Business Review.

Rothwell, R. (1993). The Changing Nature of the Innovation Process [Online] Available: http:// technopark.al.ru/ business /innovation linnovation.htm (July 12, 1993).

Smakhtina, A. (2013). Evaluation and strategies of competitiveness // Russian entrepreneurship, 2013. - No.2. - Pp. 79-85.

Zhang, Y., Zhao, S., Xu, X. (2015). Business model innovation: an integrated approach based on elements and functions. Information technology and management journal, 4, Pp. 5-8. 
